\title{
Digestive enzymes activities in Oreochromis niloticus fed diet supplemented with recombinant growth hormone
}

\section{Aktivitas enzim pencernaan pada Oreochromis niloticus yang diberi pakan mengandung hormon pertumbuhan rekombinan}

\author{
Apriana Vinasyiam, Muhammad Agus Suprayudi*, Alimuddin \\ Department of Aquaculture, Faculty of Fishery and Marine Science, Bogor Agricultural University \\ Kampus IPB Dramaga Bogor, West Java 16680 \\ Email: agusuprayudi1965@gmail.com
}

\begin{abstract}
The specific activity of the digestive enzymes, namely: pepsin, amylase, lipase, trypsin, and chymotrypsin were studied in Nile tilapia Oreochromis niloticus fed diet supplemented with recombinant Ephinephelus lanceolatus growth hormone (rElGH). The results showed that fish treated with $\mathrm{rE1GH}$ showed lower lipase and chymotrypsin specific activities $(\mathrm{P}>0.05)$, while the trypsin/chymotrypsin specific activity ( $\mathrm{T} / \mathrm{C}$ ratio) was found higher compared to control fish. Moreover, higher protein digestibility, higher protein retention and a lower ammonia excretion rate were measured for $\mathrm{rE1GH}$ treated fish. Oral rElGH administration enhanced Nile tilapia growth up to $20.04 \%$, without affecting survival. This study suggested that rapid growth performance induced by rElGH was linked with T/C ratio rather than the specific activity of other digestive enzymes.
\end{abstract}

Keywords: recombinant growth hormone, digestive enzyme, digestibility, Oreochromis niloticus

\begin{abstract}
ABSTRAK
Aktivitas spesifik enzim pencernaan pepsin, amilase, lipase, tripsin, dan kemotripsin diamati pada ikan nila Oreochromis niloticus yang diberi pakan mengandung hormon pertumbuhan rekombinan ikan kerapu kertang Ephinephelus lanceolatus (rElGH)). Hasil menunjukkan bahwa ikan uji pada perlakuan rElGH memiliki aktivitas spesifik enzim lipase dan kemotripsin yang lebih rendah, sedangkan rasio tripsin/kemotripsin (rasio T/C) yang lebih tinggi dibandingan ikan kontrol. Kecernaan protein dan retensi protein bernilai lebih tinggi sementara laju ekskresi amonia bernilai lebih rendah pada ikan perlakuan. Pemberian rElGH secara oral mampu mempercepat laju pertumbuhan ikan nila hingga 20,04\% tanpa memengaruhi kelangsungan hidup. Berdasarkan penelitian ini, dapat disimpulkan bahwa laju pertumbuhan cepat yang diinduksi oleh rElGH berhubungan dengan rasio $\mathrm{T} / \mathrm{C}$ dibandingkan dengan aktivitas spesifik enzim pencernaan lain.
\end{abstract}

Kata kunci: hormon pertumbuhan rekombinan, enzim pencernaan, kecernaan, Oreochromis niloticus

\section{INTRODUCTION}

Growth rate is a very important parameter in aquaculture that determines time required to produce marketable size of fish. Different methods oriented by molecular, environmental, and pharmacological approaches have been developed to stimulate growth rate and reduce culture time. Transgenesis (Guan et al., 2008), diet composition (Higgs et al., 2009), and other methods have been developed and showed significant results in improving growth rate. However, little attention has been paid on using recombinant growth hormone ( $\mathrm{rGH})$ (Haghighi et al., 2010).
It is generally known that growth hormone affects fish growth through both direct and indirect mechanisms (Reindl et al., 2011; Fuentes et al., 2013; Talwar et al., 2013). Direct pathway leads growth hormone to directly bind its receptor and induce growth in target cells, while in indirect pathway rGH is mediated primarily by insulin-like growth factor-I (IGF-I) produced in liver (Eppler et al., 2007, Ohlsson et al., 2009). However little is known about the actual relation between growth hormone and digestive enzyme activity.

rGH synthesis has been reported to be succesfully done in Nile tilapia Oreochromis niloticus (Acosta et al., 2007), giant grouper 
Ephinephelus lanceolatus, giant gourami Osphronemus goramy, and common carp Cyprinus Carpio (Alimuddin et al., 2010). Its activity in stimulating the growth has been documented for different fish species such as channel catfish (Silverstein et al., 2000), rainbow trout Oncorhynchus mykiss (Haghighi et al., 2010), Nile tilapia (Alimuddin et al., 2010; Bakar et al., 2012), eel Anguilla sp. (Handoyo et al., 2012), and white shrimp Litopenaeus vannamei (Subaidah, 2012).

Digestion system has been hypothesized to intensely affect the growth of fish. The quantity of nutrient used for growth is not only determined by the quantity and quality of the feed, but also by fish capability to digest the feed. That capability is strongly related to level and proportion of digestive enzyme which affect nutrient absorption in gut, and energy conversion (Lin \& Luo, 2011; Thongprajukaew et al., 2011). Present study aimed to investigate the effect of dietary supplementation of $\mathrm{rGH}$ on the digestion system using Nile tilapia as a model fish. Observation was conducted on the specific activity of digestive enzymes including protease (pepsin, trypsin, and chymotrypsin), lipase, and amylase in stomach and intestine of fish.

\section{MATERIALS AND METHODS}

\section{rGH Preparation}

Production of recombinant E. lanceolatus growth hormone (rElGH) was performed according to Alimuddin et al. (2010). Escherichia coli strain BL21 harboring the pCold-ElGH protein expression vector was used as a bioreactor to produce $\mathrm{rElGH}$. In the present study crude protein extract of rElGH was used as a feed supplement. Previous study on quantification of rElGH using CBB (coomassie brilliant blue) staining method and luminescent image analyzer (LAS-4000 mini, Fuji Film) and UN-SCAN-IT gel 6.1) showed that $1 \mathrm{~g}$ of crude protein extract of rElGH contain approximately 11,65 mg rElGH pure protein (Irmawati et al. 2013).

The presence of $\mathrm{rElGH}$ protein was verified by sodium dodecyl sulfate-polyacrylamide gel electrophoresis (SDS-PAGE) analysis, which distinguishes and characterizes proteins based on their molecular weight (Kinoshita et al. 2012). A band appearing in the position of $25 \mathrm{kDA}$ (Fig. 1 ), which was the protein molecular weight of $\mathrm{rElGH}$, characterized the presence of $\mathrm{rE} 1 \mathrm{GH}$ (Handoyo et al., 2012; Irmawati et al,. 2013).

\section{Diet preparation}

The $\mathrm{rElGH}$ at a dose of $3 \mathrm{mg}$ wet weight $/ \mathrm{kg}$ feed was determined as the working dose based on the results of our previous study (unpublished). The hormone was mixed with chicken-egg yolk $(5 \mathrm{mg} / \mathrm{kg}$ feed) as the binder. The mixture was then sprayed onto a commercial floating feed. Chicken-egg yolk was also sprayed to control feed. For digestibility test, $\mathrm{Cr}_{2} \mathrm{O}_{3}$ was also added as a tracer at a level of $0.6 \%$.

\section{Fish rearing and experimental protocol}

Nile tilapia strain NIRWANA used for the study was obtained from BPBIAT Wanayasa (West Java). Prior to experimentation, fish were acclimatized in laboratory environment for two weeks in a $500 \mathrm{~L}$ circular tank. Fish were then weighed and placed in $40 \times 50 \times 50 \mathrm{~cm}^{3}$ aquarium, previously filled with $60 \mathrm{~L}$ of fresh water, at a density of 15 individual per aquarium and at initial weight range of 5-6 g/ind. Each aquarium was equipped with aerator, heater, and individual filter. Unconsumed feed was removed daily, and $70 \%$ of the water was renewed two to three times a week. The water temperature and $\mathrm{pH}$ were maintained at the range of $28-30{ }^{\circ} \mathrm{C}$, and 6.91-7.47, respectively.

The study consisted of two treatments, fish fed with and without dietary rElGH supplementation. The rElGH-treated fish was fed with rElGH diet twice a week (with 2-3 days interval, and with non-supplemented feed for the remaining days. Treatment was administered for eigth weeks. Control fish was only fed with non-supplemented diet. Fish were fed twice a day (at 09.00 and 15.00 ) at a fixed feeding rate $4-5 \% /$ day of average fish biomass in both groups. Feed requirement for both groups were adjusted every two weeks by feeding the fish to satiation. Both groups were given the exact same amount of feed to provide the same digestive substrate quantity for the enzyme to the gut.

\section{Specific activity of digestive enzyme}

Digestive enzyme activity was measured after eight weeks of culture. Crude enzyme extract was prepared by homogenizing intestine or stomach organ separately in distilled water. The extract was then stored at $-80{ }^{\circ} \mathrm{C}$ until further analysis. Protease analysis was performed according to Walter (1988) using casein as a substrate and tyrosine as a standard. One unit specific activity of protease was defined as $1 \mathrm{mg}$ tyrosine transformed within ten minutes at $37^{\circ} \mathrm{C}$. 
The specific activity of amylase was determined according to the Bernfeld (1955) method, using starch as a substrate and maltose as a standard. One unit specific activity of amylase was expressed as $1 \mathrm{mg}$ maltose released from starch within three minutes at $20^{\circ} \mathrm{C}$ and $\mathrm{pH}$ 6.9. Specific activity of lipase was assessed based on the protocol by Borlongan (1990) with olive oil as a substrate. Fatty acid, derived from enzymatic hydrolysis of triglyceride on stabile emulsion of olive oil, was titrated with $\mathrm{NaOH}$. One unit of specific activity of lipase was determined as the volume of $\mathrm{NaOH} 0.05 \mathrm{~N}$ needed to neutralize fatty acid released after 6 hours-long incubation with substrate.

\section{Fish growth, survival, and FCR}

Sampling of total biomass per aquarium was conducted every two weeks. Survival was calculated using the following formula: survival rate $=$ number of fish alive/ number of initial fish stock in the aquarium $\times 100$. Food conversion ratio (FCR) was calculated according to Huisman (1987).

Proximate analyses, protein and lipid retention Treatment feed, initial and final fish whole body and feed were analyzed by proximate. Three fishes from each replicate tank were weighed, dissected, pooled together and analyzed. Proximate analysis was conducted according to Takeuchi (1988). The nutritional compositions of the experimental diet were shown in Table 1. Protein and lipid retention were calculated according to procedure applied by Takeuchi (1988) at the closing day of experiment.

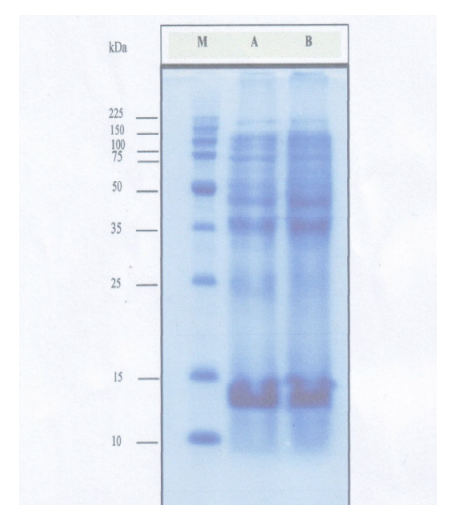

Figure 1. Result of SDS-PAGE (Sodium dodecyl sulfate-polyacrylamide gel electrophoresis) of protein recombinant Ephinephelus lanceolatus growth hormone $(\mathrm{rElGH})$. M: marker, A: crude protein of inclusion body containing $\mathrm{rElGH}$. Arrow showed rElGH protein band, number in the left showed marker size of protein molecular weight $(\mathrm{kDa})$.

\section{Blood glucose}

At the end of the rearing period, blood samples were collected from caudal veins of five individuals per treatment group and kept in Eppendorf tubes using sterile syringes. Prior to blood sampling, fish were anesthetized with 1 $\mathrm{g} / \mathrm{L}$ ether. Measurement of plasma glucose was performed by UV spectrophotometry.

\section{Liver and muscle glycogen}

Samples of liver and muscle were taken at the end of the experiment in triplicate for each replication (15 fishes/group). Glycogen content was determined according to Wedemeyer and Yasutake (1977).

\section{Digestibility test}

On the second stage of experiment, fish from the previous experiment were kept to measure different parameters characterizing digestion capacity. Digestibility test was performed using five replicates with a density of 8 fishes/aquarium. Fish were feed with $\mathrm{Cr}_{2} \mathrm{O}_{3}$-supplemented feed for two weeks. Feces were collected twice daily every 30 minutes after meal and immediately stored in the freezer at temperature of $0{ }^{\circ} \mathrm{C}$ until further analysis. Protein and total digestibility were calculated according to Law (1986).

\section{Ammonia excretion rate}

On the third stage of experiment, ammonia excretion rate was obtained according to the method described by Yigit and Ergun (2005). Fish from digestibility-test batch were weighed and classified into groups that consisted of 3 fish with similar biomass. Nitrogen excretion was measured using three aquarium replicates with 3 fishes/aquarium. After the completion of feeding activity (within 30 minutes), fish in each group were transferred into other identical tanks filled with $60 \mathrm{~L}$ of previously aerated freshwater. No feeding, aeration, nor water renewal were applied during the experiment ( $24 \mathrm{~h})$.

Samples of water were taken at $\mathrm{HO}$ (Hour 0), H2, H4, H6, and H24. Ammonia and nitrite concentration were determined using Phenate Method (APHA, 1998). The ammonia excretion rate was calculated with the formula: $A=[(\mathrm{N} 2-$ N1) $x$ V2] / W / T2-1. Where A = ammonia excretion rate, $\mathrm{N} 1=$ ammonia concentration at time $1(\mu \mathrm{g}), \mathrm{N} 2=$ ammonia excretion at time 2 $(\mu \mathrm{g}), \mathrm{V} 2=$ volume of the medium at time $2, \mathrm{~W}=$ wet weight of the fish (g), T2-1 = time interval between sampling 1 and 2 (h). 


\section{Data analysis}

Data of both treatments were compared using one-way ANOVA (F-test). The data were analysed using SPSS 18 software. Significant differences were noted if only criteria of $\mathrm{p}$-value were more than $0.05(\mathrm{P}<0.05)$

\section{RESULT AND DISCUSSION}

\section{Result}

There was no significant difference in moisture, ash and fiber content (Table 2) between the two groups of fish $(\mathrm{P}>0.05)$. Significantly higher crude protein, crude lipid and NFE contents, was observed in rElGH-treated fish as compared to the control $(\mathrm{P}<0.05)$.

No effect was noted for specific activities of most digestive enzymes $(\mathrm{P}>0.05)$. Lipase and chymotrypsin specific activity of rElGH-treated fish were lower $(\mathrm{P}<0.05)$, while specific activity of $\mathrm{T} / \mathrm{C}$ ratio was higher $(\mathrm{P}<0.05)$ than those of control fish (Table 3). In addition, rElGH-treated fish had protein digestibility $3.65 \%$ higher $(\mathrm{P}<0.05)$ than those of control treatment, while total digestibility was not significantly different ( $\mathrm{P}>0.05)$ as compared to the control (Tabel 4).

Glycogen and blood glucose levels were presented in Table 4. The rElGH in present study has tremendously increased muscle glycogen deposition as much as $149.34 \%$. In contrast, control fish showed a $16.97 \%$ higher blood glucose level than rElGH-treated fish. No signficant difference was found in liver glycogen concentration between groups $(\mathrm{P}>0.05)$. Protein and lipid retention of rElGH-treated fish were respectively $14.56 \%$ and $23.53 \%$ higher $(\mathrm{P}<0.05)$ compared to control fish.

At the end of rearing period (week-8) the individual weight of rElGH-treated fish was significantly higher $(\mathrm{P}<0.05)$ than the control (Table 5). The survival levels of rElGH-treated and control fish were not statistically different $(\mathrm{P}>0.05)$. Ammonia excretion rate in $\mathrm{rElGH}$ treatment was significantly lower $(\mathrm{P}<0.05)$ than in the control (Table 5). Dietary rElGH administration could improve FCR (Table 5) by $16.72 \%(\mathrm{P}<0.05)$.

\section{Discussion}

Compare to control fish no effect was noted for specific activities of most digestive enzymes $(\mathrm{P}>0.05)$, except those for lipase and chymotrypsin. The lower level of specific activity of lipase in rElGH-treated fish possibly indicated

Table 1. Proximate composition of feed supplemented with recombinant Ephinephelus lanceolatus growth hormone $(\mathrm{rElGH})$ and control feed (non-rElGH) in dry basis.

\begin{tabular}{ccc}
\hline Parameter & Feed + rElGH & Feed non-rElGH \\
\hline Moisture (\%) & 12.47 & 11.07 \\
Ash (\%) & 8.47 & 8.82 \\
Crude protein (\%) & 27.81 & 28.57 \\
Crude lipid (\%) & 4.91 & 5.01 \\
Crude fiber (\%) & 3.97 & 42.37 \\
NFE (\%)* & 4.64 & 41.89 \\
\hline
\end{tabular}

*NFE $=$ Nitrogen-free extract.

Table 2. Proximate composition (mean \pm standard deviation) of recombinant Ephinephelus lanceolatus growth hormone (rElGH)-treated and control (whole body).

\begin{tabular}{ccc}
\hline Parameter & rElGH & Control \\
\hline Moisture (\%) & $74.95 \pm 0.54 \mathrm{a}$ & $75.84 \pm 0.52 \mathrm{a}$ \\
Ash $(\%)$ & $3.95 \pm 0.06 \mathrm{a}$ & $3.81 \pm 0.07 \mathrm{a}$ \\
Crude protein $(\%)$ & $14.64 \pm 0.10 \mathrm{~b}$ & $14.31 \pm 0.19 \mathrm{a}$ \\
Crude lipid (\%) & $5.97 \pm 0.20 \mathrm{~b}$ & $5.60 \pm 0.18 \mathrm{a}$ \\
Crude fiber $(\%)$ & Not detected & Not detected \\
NFE $(\%)^{*}$ & $0.06 \pm 0.03 \mathrm{a}$ & $0.17 \pm 0.03 \mathrm{~b}$ \\
\hline
\end{tabular}

Different superscript letter in the same row indicated different effect of the treatment $(\mathrm{P}<0.05)$. $*$ NFE $=$ Nitrogenfree extract. 
Table 3. Specific activity of digestive enzymes (mean \pm standard deviation) in recombinant Ephinephelus lanceolatus growth hormone (rElGH)-treated and control fish.

\begin{tabular}{|c|c|c|}
\hline Parameter & $\mathrm{rElGH}(\mu \mathrm{g} / \mathrm{mg}$ protein $)$ & Control ( $\mu \mathrm{g} / \mathrm{mg}$ protein) \\
\hline Pepsin & $0.19 \pm 0.02 \mathrm{a}$ & $0.18 \pm 0.02 \mathrm{a}$ \\
\hline Amylase & $9.85 \pm 0.78 \mathrm{a}$ & $9.64 \pm 1.58 \mathrm{a}$ \\
\hline Lipase & $1.56 \pm 0.35 \mathrm{a}$ & $4.95 \pm 0.55 b$ \\
\hline Trypsin & $0.05 \pm 0.01 \mathrm{a}$ & $0.06 \pm 0.03 a$ \\
\hline Chymotrypsin $\left(\times 10^{-3}\right)$ & $0.50 \pm 0.02 \mathrm{a}$ & $41.3 \pm 12.6 b$ \\
\hline T/C ratio* & $93.40 \pm 3.43 b$ & $1.57 \pm 0.12 \mathrm{a}$ \\
\hline
\end{tabular}

Different letter in the same row indicate significant difference $(\mathrm{P}<0.05) . * \mathrm{~T} / \mathrm{C}$ ratio $=$ trypsin/chymotrypsin ratio.

Table 4. Digestibility, glycogen, glucose, protein and lipid retention (mean \pm standard deviation) in recombinant Ephinephelus lanceolatus growth hormone (rElGH)-treated and control fish.

\begin{tabular}{lcc}
\hline \multicolumn{1}{c}{ Parameter } & rElGH & Control \\
\hline Protein digestibility (\%) & $89.32 \pm 0.99 \mathrm{~b}$ & $86.18 \pm 1.23 \mathrm{a}$ \\
Total digestibility $(\%)$ & $64.66 \pm 0.52 \mathrm{a}$ & $63.50 \pm 0.57 \mathrm{a}$ \\
Muscle glycogen $(\mathrm{mg} / \mathrm{g})$ & $3.94 \pm 0.32 \mathrm{~b}$ & $1.58 \pm 0.51 \mathrm{a}$ \\
Liver glycogen $(\mathrm{mg} / \mathrm{g})$ & $1.54 \pm 0.64 \mathrm{a}$ & $1.40 \pm 0.53 \mathrm{a}$ \\
Blood glucose $(\mathrm{mg} / \mathrm{dL})$ & $67.79 \pm 6.06 \mathrm{a}$ & $81.65 \pm 11.41 \mathrm{~b}$ \\
Protein retention $(\%)$ & $38.39 \pm 1.80 \mathrm{~b}$ & $33.51 \pm 3.61 \mathrm{a}$ \\
Lipid retention $(\%)$ & $91.16 \pm 4.36 \mathrm{~b}$ & $73.80 \pm 7.12 \mathrm{a}$ \\
\hline
\end{tabular}

Different letter in the same row indicated different effect of the treatment $(\mathrm{P}<0.05)$.

Table 5. Individual weight, survival rate (SR), ammonia excretion rate, and food conversion ratio (FCR) (mean \pm standard deviation) of recombinant Ephinephelus lanceolatus growth hormone (rElGH)-treated and control fish.

\begin{tabular}{lcc}
\hline \multicolumn{1}{c}{ Parameter } & rElGH & Control \\
\hline Individual weight $(\mathrm{g})$ & $33.72 \pm 1.23 \mathrm{~b}$ & $29.06 \pm 1.16 \mathrm{a}$ \\
SR $(\%)$ & $90.00 \pm 3.33 \mathrm{a}$ & $86.67 \pm 4.71 \mathrm{a}$ \\
Ammonia excretion rate $(\mu \mathrm{g} / \mathrm{g}$ fish per hour) & $4.40 \pm 0.22 \mathrm{a}$ & $5.20 \pm 0.35 \mathrm{a}$ \\
FCR & $1.44 \pm 0.07 \mathrm{a}$ & $1.72 \pm 0.09 \mathrm{~b}$ \\
\hline
\end{tabular}

Different letter in the same row indicated different effect of the treatment $(\mathrm{P}<0.05)$.

the relation between lipase and $\mathrm{rGH}$. However, results were not sufficient to explain how growth hormone influences lipase. In contrast, a study held by (Irmawati et al., 2013) showed that the application of carp $\mathrm{rGH}(\mathrm{rCcGH})$ on giant gourami increases the level of lipase specific activity and the amount of feed intake by the fish. These findings suggested that the secretion of digestive enzymes is determined by the amount of digestion substrate coming to the gut rather than the concentration of recombinant growth hormone in fish.

This study showed that control fish had higher specific activity of chymotrypsin $(\mathrm{P}<0.05)$ while no effect was found in trypsin specific activity
( $\mathrm{P}>0.05)$. Blier et al. (2002) found no significant differences between transgenic with higher growth rate and non-trasngenic Coho salmon O. kisutch for specific activity of trypsin and chymotrypsin. A similar study on transgenic Atlantic cod (Lemieux et al., 1999) found positive correlations between growth rate, trypsin, and chymotrypsin specific activities. The effect of hormonal manipulation on digestive enzyme activity may be species specific.

Chymotrypsin is a digestive protease, which will increase when fish growth is suppressed (Torissen et al., 2006). Stress indication has been possibly induced by fish handling during experiment by weight sampling done every two 
weeks thus possibly causing a reduction in fish growth (Tahmasebi-Kohyani et al., 2012). It is possible that $\mathrm{rE} 1 \mathrm{GH}$ reduce stress in fish, thus explaining the higher level of chymotrypsin also blood glucose measured in control fish. Changes on the level of chymotrypsin or blood glucose are determined as physiological effects of stress condition in fish (Barreto \& Volpato, 2006; Solati \& Falahatkar, 2007; Chan et al., 2008).

Another noteworthy parameter was the specific activity of trypsin and chymotrypsin (T/C) ratio. In this research, T/C ratio was linear with tilapia growth. Consistent with this result, previous researches on $\mathrm{T} / \mathrm{C}$ ratio demonstrated a positive correlation between $\mathrm{T} / \mathrm{C}$ ratio and growth rate (Blier et al., 2002; Torissen et al., 2006). These findings suggested that higher growth in tilapia treated with rElGH was not mediated by digestive enzyme activities but might be related to the T/C ratio. Future research is expected to investigate the mechanism of either growth or growth hormone action in relation with T/C ratio.

As the diet was relatively the same, difference in protein digestibility might be due to higher digestion and absorption processes in gut. There was similarity between transgenic and rGHtreated fish as they have more growth hormone than fish without treatments. Study held by Stevens et al. (1999) showed that transgenic Atlantic salmon has a larger digestive surface area both in the anterior intestine (surface area 1.5 times control) and in the pyloric caeca (surface area 1.2 times control). Stevens and Devlin (2000) found that transgenic Coho salmon had a 2.2-fold larger surface area of total intestine than non-transgenic fish. These studies suggest that growth hormone can increase the level of protein absorption as the protein digestion.

The rElGH-treated fish displayed a lower level of blood glucose and liver glycogen, but a higher muscle glycogen than compared to the control. The rElGH-treated fish were suggested to be more capable to absorb and utilize carbohydrate in feed to fulfill its energy need, known as protein sparring effect (Hasan \& Khan, 2013). Rapid growth required greater energy and higher level of blood glucose to be converted. Thus, the lower level of blood glucose observed in rElGH-treated fish could be explained by the higher conversion rate of glucose into energy.

Few hours after food is ingested, blood glucose level increases and the excess glucose is saved as glycogen in muscle and liver involving insulin hormone (Yilmaz et al., 2015). Glycogen acts as an additional energy source which can be converted if glucose level does not fulfill the energy need through glycogenolysis (Leung \& Woo, 2012; Västermark \& Saier; 2014). Muscle glycogen conversion is only used to fulfill energy need in local muscle where it is saved, while liver glycogen can be used for whole body-energy need (Felip et al., 2013; Jørgensen et al., 2013; Gaillard et al., 2015). Higher muscle glycogen in $\mathrm{rElGH}$ treated fish is generally followed by higher liver glycogen. However, in present study similar levels of liver glycogen were observed in both groups as some of the liver glycogen in rElGH-treated fish has been converted into glucose to make energy for the whole body. Muscle glycogen conversion did not occur because the energy from glucose and liver glycogen were still sufficient to fulfill muscle energy need, whereas in control, muscle glycogen was lower because less glucose being converted into it due to lower level of carbohydrat digestion

A higher lipid and protein retention measured in rElGH-treated fish has led to higher lipid and protein deposition than in control fish. In this study, higher protein level measured in flesh and lower ammonia excretion level were found in rElGH-treated fish $(\mathrm{P}<0.05)$. At the end of the rearing period (week eight), individual weight of rElGH-treated fish was $20.04 \%$ higher $(\mathrm{P}<0.05)$ than those of control. Less ammonia excretion implied that amino acid deamination in the liver was decreased thus optimizing nitrogen used for the fish growth (Guo et al., 2012). This study also revealed that the administration of $\mathrm{rElGH}$ had no negative effect $(\mathrm{P}>0.05)$ on the survival of fish.

In conclusion, the present study demonstrated that oral administration of rElGH at level of $3 \mathrm{mg} /$ $\mathrm{kg}$ of feed had no effect on specific activity of pepsin, amylase, and trypsin, but showed lower level in lipase and chymotrypsin in Nile tilapia. There might be a possibility that there is no direct relation between growth hormone and digestive enzymes, however growth could be related to the $\mathrm{T} / \mathrm{C}$ ratio. This study also identified that $\mathrm{rElGH}$ treated fish performed a higher protein digestion, and protein retention in the body, but a lower ammonia excretion rate were obtained to support the enhanced growth of the fish.

\section{ACKNOWLEDGMENT}

The authors wish to thank the assistance of the staff and technicians of the Departement of Aquaculture, Faculty of Fishery and Marine 
Science, Bogor Agricultural University. A special thank also goes out to Wanayasa Freshwater Seed Development Center, West Java for the experimental fish used in this study.

\section{REFERENCES}

Acosta J, Morales R, Morales A, Alonso M, Estrada MP. 2007. Pichia pastoris expressing recombinant tilapia growth hormone accelerates the growth of Tilapia. Biotechnology Letters 29: 1.671-1.676.

Alimuddin, Lesmana I, Sudrajat AO, Carman O, Faizal I. 2010. Production and bioactivity potential of three recombinant growth hormones of farmed fish. Indonesian Aquaculture Journal 5: 11-17.

APHA [American Public Health Association]. 1998. Standard Methods for the Examination of Water and Waste Water, 20th Edition. USA: APHA.

Bakar AMSA, Wong CMVL, Mustapha S. 2012. Growth effect of recombinant growth hormone of mouse garoupa Cromileptes altivelis on tilapia fingerlings. Sabah, Malaysia: University Malaysia Sabah.

Barreto RE, Volpato GI. 2006. Stress responses of the Nile tilapia subjected to electroshock and social stressors. Brazilian Journal of Medical and Biological Research 39: 1.605-1.612.

Bernfeld P. 1955. Introduction to Nutrition and Metabolism. London, UK: Taylor and Francis.

Blier PU, Lemieux H, Devlin RH. 2002. Is the growth rate of fish set by digestive enzymes or metabolic capacity of the tissues? Insight from transgenic Coho salmon. Aquaculture 209: 379-384.

Borlongan TG. 1990. Studies on the lipases of milkfish Chanos chanos. Aquaculture 89: 315-325.

Chan CR, Lee DN, Cheng YH, Hsieh DJY, Weng CF. 2008. Feed deprivation and re-feeding on alterations of proteases in tilapia Oreochromis mossambicus. Zoological 47: 207-214.

Eppler E, Caelers A, Shved N, Hwang G, Rahman AM, Maclean N. Zapf J, Reinecke M. 2007. Insulin-like growth factor I (IGF-I) in a growthenhanced transgenic (GH-overexpressing) bony fish, the tilapia Oreochromis niloticus: Indication for a higher impact of autocrine/ paracrine than of endocrine IGF-I. Transgenic Res. 16: 479-89.

Felip, O., Blasco, J., Ibarz, A., Martin-Perez, M., \& Fernández-Borràs, J. (2013). Beneficial effects of sustained activity on the use of dietary protein and carbohydrate traced with stable isotopes $15 \mathrm{~N}$ and $13 \mathrm{C}$ in gilthead sea bream (Sparus aurata). Journal of Comparative Physiology B 183: 223-234.

Fuentes EN, Valdes JA, Molina A, Björnsson BT. 2013. Regulation of skeletal muscle growth in fish by the growth hormoneinsulin-like growth factor system. General and Comparative Endocrinology 192: 136-148.

Gaillard M, Bernatchez L, Tremblay R, Audet C. 2015. Regional variation in energy storage strategies in American glass eels from Eastern Canada. Comparative Biochemistry and Physiology Part A. Molecular and Integrative Physiology 188: 87-95.

Guan B, Hu W, Zhang T, Wang Y, Zhu Z. 2008. Metabolism traits of 'all fish' growth hormone transgenic common carp Cyprinus carpio L. Aquaculture 284: 217-223.

Guo ZQ, Zhu XM, Liu JS, Han D, Yang YX, Lan ZQ, Xie SQ. 2012. Effects of dietary protein level on growth performance, nitrogen and energy budget of hybrid sturgeon Acipenser baerii $\times$ A. gueldenstaedtii . Aquaculture 338341: 89-95.

Haghighi M, Sharif RM, Sharifpour I, Sepahdari A, Lashtoo AGR. 2010. Oral recombinant bovine somatotropin improves growth performance in rainbow trout Oncorhynchus mykiss. Iranian Journal of Fisheries Sciences 10: 415-424.

Handoyo B, Alimuddin, Utomo NBP. 2012. Growth, feed conversion and retention, and proximate of eel juvenile treated by immersion of recombinant giant grouper growth hormone. Jurnal Akuakultur Indonesia 11: 132-140.

Hasan AJZ, Khan U. 2013. Protein sparring effect and the efficiency of different compotitions of carbohydrates, lipids and protein on the growth of rohu Labeo rohita fingerlings. World Journal of Fish Marine Science 5: 244-250.

Higgs DA, Sutton JN, Kim H, Oakes JD, Smith J, Biagi C, Rowshandeli M, Devlin RH. 2009. Influence of dietary concentration of protein, lipid, and carbohydrate on growth, protein, and energy utilization, body composition, and plasma titres of growth hormone and insulin-like growth factor-1 in non-tramsgenic and growth hormone trasgenic Coho salmon, Oncorhyncus kisutch (Walbaum). Aquaculture 286: 127-137.

Huisman E.A. 1987. The Principles of Fish Culture Production. Wageningen, Netherland: 
Departement of Aquaculture, Wageningen University. 100 pp.

Irmawati, Alimuddin, Junior MZ. 2012. Growth enhancement of juvenile Osphronemus goramy Lac. emmersed in water containing recombinant Cyprinus carpio growth hormone. Jurnal Iktiologi Indonesia 12: 13-23.

Jørgensen EH, Martinsen M, Strom V, Hansen KER, Ravuri CS, GongN, Jobling M. 2013. Long-term fasting in the anadromous Arctic charr is associated with downregulation of metabolic enzyme activity and upregulation of leptin A1 and SOCS expression in the liver. The Journal of Experimental Biology 216: 3.222-3.230.

Kinoshita E, Kinoshita-Kikuta E, Koike T. 2012. Phos-tag SDS-PAGE systems for phosphorylation profiling of proteins with a wide range of molecular masses under neutral pH conditions. Proteomics 12: 192-202.

Law AT. 1986. Digestibility of low-cost ingredients in pelleted feed by grass carp Ctenopharyngodon idella C. Aquaculture 51: 97-103.

Lemieux H, Blier P, Dutil JD. 1999. Do digestive enzymes set a physiological limit on growth rate and food conversion efficiency in the Atlantic cod Gadus morhua? Fish Phsyology and Biochemistry 20: 293-303.

Leung LY, Woo NY. 2012. Influence of dietary carbohydrate level on endocrine status and hepatic carbohydrate metabolism in the marine fish Sparus sarba. Fish Physiology and Biochemistry 38: 543-554.

Lin S, Luo L. 2011. Effects of different levels of soybean meal inclusion in replacement for fish meal on growth, digestive enzymes and transaminase activities in practical diets for juvenile tilapia Oreochromis niloticus $\times O$. aureus. Animal Feed Science and Technology 168: 80-87.

Ohlsson C, Mohan S, Sjogren K, Tivesten A, Isgaard J, Isaksson O, Jansson JO, Svensson J. 2009. The role of liver-derived insulinlike growth factor-I. Endocrine Reviews 30: 494-535.

Reindl KM, Kittilson JD, Bergan HE, Sheridan MA. 2011. Growth hormone-stimulated insulin-like growth factor-1 expression in rainbow trout Oncorhynchus mykiss hepatocytes is mediated by ERK, PI3KAKT, and JAK-STAT. American Journal of Physiology-Regulatory, Integrative and
Comparative Physiology 301: 236-243.

Silverstein JT, Wolters WR, Shimizu M, Dickhoff WW. 2000. Bovine growth hormone treatment of channel catfish: strain and temperature effects on growth, plasma IGF-I levels, feed intake and efficiency and body composition. Aquaculture 190: 77-88.

Solati NH, Falahatkar B. 2007. Stress responses in sub-yearling great sturgeon to the air exposure. Caspian Journal Environment Science 5: 99-103.

Stevens ED, Devlin RH. 2000. Intestinal morphology in growth hormone transgenic Coho salmon. Journal of Fish Biology 56: 191-195.

Stevens ED, Wagner GN, Sutterlin A. 1999. Gut morphology in growth hormone transgenic Atlantic salmon. Journal of Fish Biology 55: 517-526.

Subaidah S. (2012) Respons pertumbuhan dan ekspresi gen udang vaname Litopenaeus vannamei setelah direndam dalam larutan hormon pertumbuhan rekombinan ikan kerapu kertang. Jurnal Riset Akuakultur 7: 359-369.

Tahmasebi-Kohyani A, Keyvanshokooh S, Nematollahi A, Mahmoudi N, PashaZanoosi H. 2012. Effects of dietary nucleotides supplementation on rainbow trout Oncorhynchus mykiss performance and acute stress response. Fish Physiology and Biochemistry 38: 431-440.

Takeuci T. 1988. Laboratory work-cheical evaluation of dietary nutrients. In: Watanabe T, (ed). Fish Nutrition and Mariculture. Kanagawa, Japan: Kanagawa International Fisheries Training Center. 179-233 pp.

Talwar GP, Pandian MR, Kumar N, Hanjan SNS, Saxena RK. 2013. Mechanism of action of pituitary growth hormone. In Recent Progress in Hormone Research: Proceedings of the 1974 Laurentian Hormone Conference 31: 141-145.

Thongprajukaew K, Kovitvadhi U, Kovitvadhi S, Somsueb P, Rungruangsak-Torrissen K. 2011. Effects of different modified diets on growth, digestive enzyme activities and muscle compositions in juvenile Siamese fighting fish Betta splendens (Regan, 1910). Aquaculture 322: 1-9.

Torissen KR, Moss R, Andresen LH, Berg A, Waagbo R. 2006. Different expressions of trypsin and chymotrypsin in relation to growth in Atlantic salmon Salmo salar L. Fish Physology and Biochemistry 32: 7-23. 
Västermark A, Saier MH. 2014. The involvement of transport proteins in transcriptional and metabolic regulation. Current Opinion in Microbiology 18: 8-15.

Walter HE. 1984. Method with haemoglobin, casein and azocoll as substrate. In: Bergmeyer HU, (ed). Methods of Enzymatic Analysis vol. V. Weinheim, Germany: Verlag Chemie. 270-277 pp.

Wedemeyer GA, Yasutake WT. 1977. Clinical Method for The Assessment of The Effect of Environmental Stress on Fish Health [Technical Papper]. Washington DC, USA: US Fish Wildlife Service. Hlm. 89.
Yigit M, Ergun S. 2005. Using ammonia nitrogen excretion rates as an index for evaluating protein quality of prawns in turbot Psetta maeoticanutrition. Turkish Journal of Veterinary and Animal Science 29: 1.343-1.349.

Yilmaz FÖ, Engin K, Hunt AÖ. 2015. The effects of balanced diets with soy bean extract or meat and bone meal on muscle and liver tissue protein and glycogen levels of the Nile tilapia Oreochromis niloticus infected with Vibrio anguillarum. Journal of Applied Biological Sciences 9: 37-42. 